IRSH 49 (2004), Supplement, pp. 87-I09 DOI: I0.10I7/S0020859004001658 (C) 2004 Internationaal Instituut voor Sociale Geschiedenis

\title{
Unemployed Intellectuals in the Sahara: The Teshumara Nationalist Movement and the Revolutions in Tuareg Society*
}

\author{
B A Z LECOCQ
}

Summary: In the past four decades the Tuareg, a people inhabiting the central Sahara, experienced dramatic socioeconomic upheaval caused by the national independence of the countries they inhabit, two droughts in the I970s and I980s, and prolonged rebellion against the state in Mali and Niger in the I990s. This article discusses these major upheavals and their results from the viewpoint of three groups of Tuareg intellectuals: the "organic intellectuals" or traditional tribal leaders and Muslim religious specialists; the "traditional intellectuals" who came into being from the I950s onwards; and the "popular intellectuals" of the teshumara movement, which found its origins in the drought-provoked economic emigration to the Maghreb, and which actively prepared the rebellions of the I990s. By focusing on the debates between these intellectuals on the nature of Tuareg society, its organization, and the direction its future should take, the major changes in a society often described as guarding its traditions will be exposed.

\section{INTRODUCTION}

"In this still untamed Sahara - among the camel herdsmen, young Koranic students, government officials, and merchants now anticipating a more peaceful and prosperous future - we were seeking rhythms of life unbroken since the time of Muhammad, I,300 years ago."

When the Tuareg rebellions in Mali and Niger ended in the second half of the I990s, journalists set out to look for the unchanging character of Saharan life, ruled by tradition and ways as old as mankind. They quickly discovered that the "veiled blue men of the desert" no longer travel by camel caravans, but in four-wheel drives and trucks, that their feet are no

* Research for this article has been funded through grants offered by the Amsterdam School for Social Science Research, and the Netherlands Organization for Scientific Research (NWO-SIR I 2-3958, NWO-SIR I I-I 840 and NWO-CNRS F 24-823). I would like to thank Greg Mann, the members of the Sahel Club, and Rosanne Rutten for their comments and suggestions. Of course, all errors are mine.

I. Donovan Webster, "Journey to the heart of the Sahara", National Geographic, 195:3 (March I999), pp. 6-33, II. 


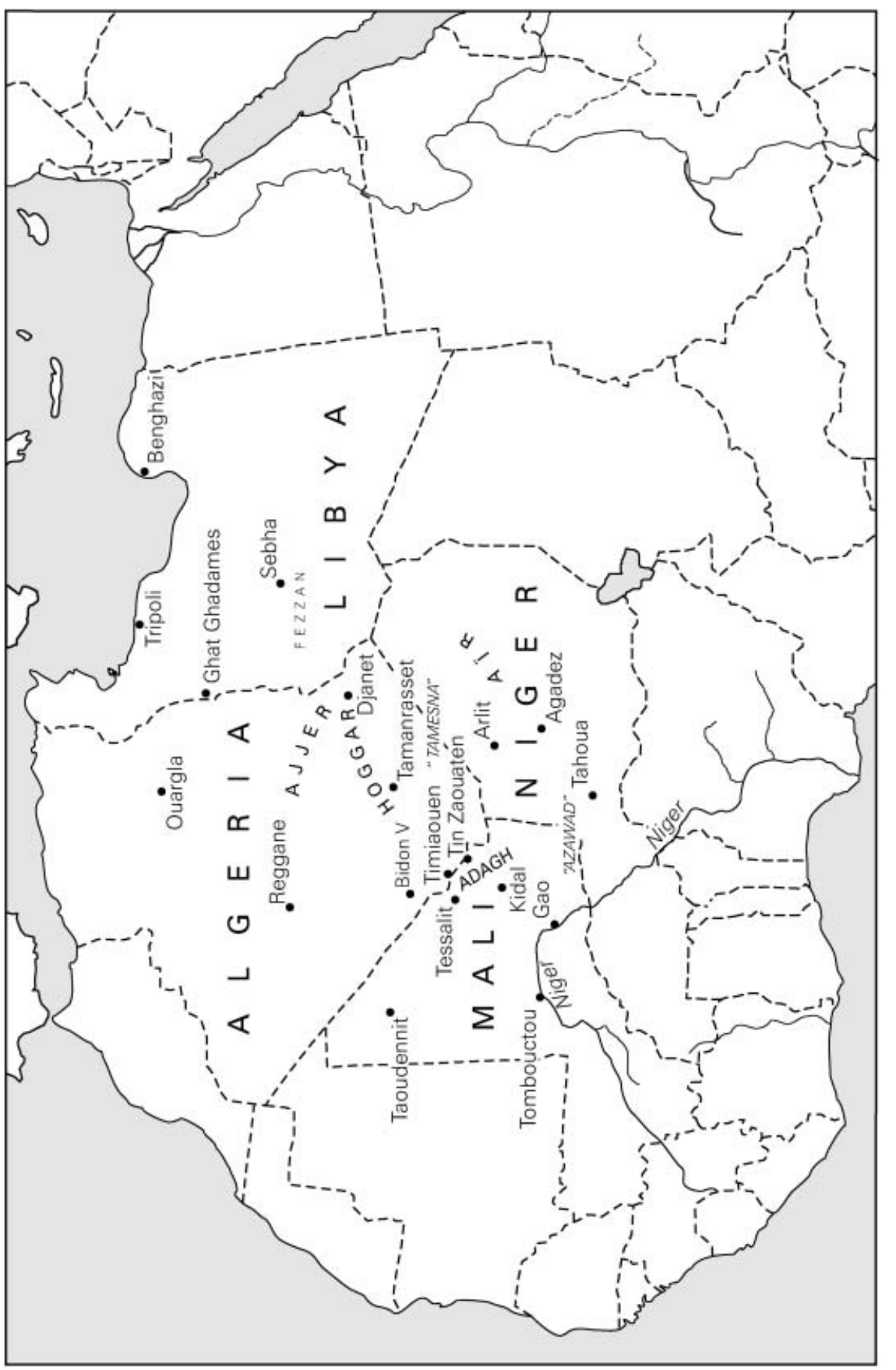

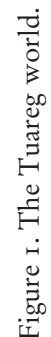


longer scorched by burning sand as they wear sneakers, that their mysterious eyes are no longer visible above their veil as they wear sunglasses, that, in short, the Tuareg are as much touched by modern existence as the next person.

The Tuareg are a pastoral nomad people inhabiting the central Saharan mountain ranges of the Ajjer in Libya, the Hoggar in Algeria, the Adagh in Mali, the Air in Niger, and the interior bend of the Niger river in Mali, Niger, and Burkina Faso. They speak a Berber language, called Tamasheq, and trace their origins to various places in the Maghreb and Libya. At the advent of colonial conquest, the Tuareg held political control over a vast stretch of the Sahara, and had the military upper hand over neighbouring peoples to the south. After fierce resistance against colonial conquest and pacification between I 893 and I9I7, the Tuareg signed their peace with the French. Due to a lack of economic interest in the area, the colonial administration largely left them to their own devices as long as they did not disturb la paix française. A certain fascination for the nomad Tuareg, epitomizing nomadic freedom and chivalry in an orientalist fashion, led French colonial administrators to endeavour to "conserve" their way of life. As the anthropologist Jeremy Keenan formulated it: "The idea of a Tuareg reserve, in which the traditional form of society would, as far as possible, be protected and allowed to regulate its own internal affairs, was never far removed from the directives of policy."

In the last four decades, Tuareg society underwent drastic changes. First, the newly independent states which encompassed Tuareg populations put their modernity drives at full speed. They perceived the pastoral nomad way of life of the Tuareg as backward and undesirable. Nomads should be sedentarized and educated. In I963, a first small-scale rebellion broke out in Mali against these modernization policies, which the Tuareg perceived as a "recolonization" of their society. It was bloodily crushed, after which the survivors retreated into Algeria. ${ }^{3}$ A second, even more important impetus to change were the droughts that struck the Sahel in the I970s and I980s. These virtually annihilated Tuareg herds which still formed the economic basis of society. The victims of these droughts were confronted with insufficiency of relief aid and state corruption in its distribution, as it was diverted and sold. ${ }^{4}$ Those who were still able-bodied left for the urban centres of the Maghreb and West Africa, looking for work. Here, they were confronted with illegality, discrimination, and, from the late ig8os onwards, expulsion. Thus, a generation of Tuareg, born in the I950s, grew up with forced sedentarization and education, social economic destruction

2. Jeremy Keenan, The Tuareg: People of Ahaggar (London, 2002), p. I37.

3. See Baz Lecocq, “That Desert is Our Country': Tuareg Rebellions and Competing Nationalisms in Contemporary Mali (1946-1996)", (Ph.D., Amsterdam University, 2002).

4. See Hal Sheets et al., Disaster in the Desert: Failures of International Relief in the West African Drought (Washington DC, 1974). 
by drought and state agents, and social economic marginality in the nationstates ruling their land. This led to strong resentment. As one of my informants put it:

I grew up seeing all this, and in my youthfulness I took a really, really strong hatred. In those years an incredibly grave obligation fell upon us. It was they who owned us, like hostages. All young people of my age in that period had the same hatred, the same sentiment of being re-colonized, and that caused a great feeling of hate in us. ${ }^{5}$

In June I990, a small group of young Tuareg men started an armed uprising against the Malian state. In 1992, their example was followed by colleagues in Niger. These are generally known as the Tuareg rebellions. The Malian rebellion first formally ended in I992, but violence continued between various Tuareg rebel factions and the Malian army. The conflict reached its height in 1994, with inter-ethnic conflicts between Tuareg rebels and a vigilante movement of the neighbouring Songhay people. After petering out at the end of 1994, the conflict was formally ended in March 1996. In Niger, a first peace was signed in October 1994, followed by treaties signed with breakaway factions in April 1995, January 1997, and, finally, June 1998.

The rebellions are generally described as low-intensity conflicts, because of the sporadic battles and the small absolute number of deadly victims (a few thousand), and internally displaced persons and international refugees (perhaps 250,000). However, if one considers that the rebellions took place in two of the world's poorest countries, in those parts of those countries generally considered the least favoured, that the conflict area is a naturally fragile environment, collapsed under ecological disasters which had totally disrupted local society and economy, one can imagine these rebellions to be of the gravest kind possible. Yet, the rebellions were started with the intention of improving living conditions through national independence, and to save Tuareg society from oblivion by altering its socio-political structures. These goals were set by a small group of young intellectuals and informal leaders of the generation born in the i950s. A small group of these men had started to prepare for armed conflict since the late i970s.

In this article, I will first describe these new Tuareg intellectuals. They can be divided into roughly two groups: the Western-educated, generally

Figure 2 (see opposite page). Two young ishumar have their picture taken somewhere in Libya in 1972. The young man in black is Iyad ag Ghali, the future leader of the rebellion in Mali (1990-1996), then eighteen years old. Note the flared trousers, the "soul" boots, and the Libyan gandoura, as well as the absence of a turban.

Photograph courtesy of Mohamed Lamine ag Mohamed Fall, the other person in the picture.

5. Interview with Mohamed Lamine ag Mohamed Fall, Kidal, 27 December 1998. 


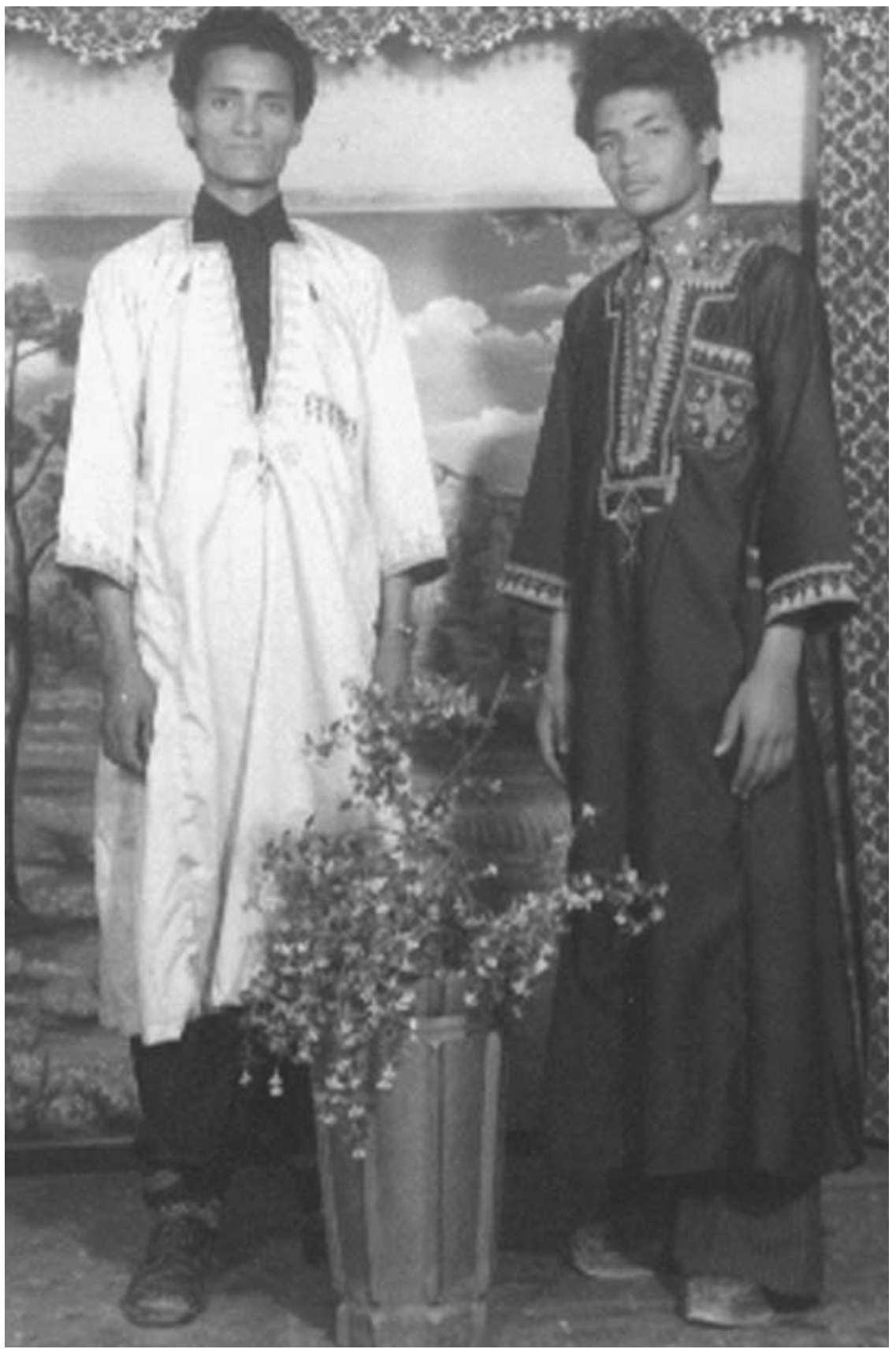


called évolués, and a group of autodidacts generally called ishumar. I will then describe the subjects of their reflection and the debates between them from the I970s to the I990s. These debates centred around two major themes: nation and society. The ishumar were largely responsible for the rethinking of the Tuareg nation and its desired independence from the existing nation-states. The évolués focused on the nature of Tuareg society, as based on pastoral nomadism and social hierarchy expressed through social strata in which one was born, and tribal affiliation. Both groups of intellectuals expressed the need to change society from hierarchical tribal pastoralism to one based on equality between members, and a diversified social economy. Disagreement on the importance of both subjects and mutual resentment were not exceptional. On both issues however, the younger generation of intellectuals united in their confrontation with an older elite of tribal leaders and "traditional" Muslim intellectuals who had interests in a social and political (but not an economic) status quo. It is not exaggerated to describe the conflicts as a generational conflict between an upcoming and an established elite. I will describe how before, during, and after the rebellion, both groups of young intellectuals developed, and how they tried to change society. In the end, we will see that most of their attempts proved ineffective.

\section{TRADITIONAL AND POPULAR INTELLECTUALS}

Until the late I940s, Tuareg society knew but one type of intellectual, of the sort that Gramsci described as "organic". In Tuareg society these are the so called ineslemen or alfaqiten, Muslim religious specialists serving as mediators and spiritual guides. They could also be seen as "traditional" intellectuals in the Gramscian sense. They are, however, part of the political elite. The second group of these "organic intellectuals" consists of the tribal chiefs, who function as tribal councillors and mediators between authorities and population. Together these groups form the ruling elite, creating and enforcing social and civil law. As Tim Carmichael remarks with reference to the colonial Swahili Coast, Gramsci's conception of law corresponds with that of many Muslim and African societies, where "there is no effective division between religious and civil societies, and where law is subsumed under religion". ${ }^{6}$ These two groups of organic intellectuals will be presented here as the traditional elite. They can be characterized on a political level as conservative.

The évolués can only partly be described in a Gramscian sense as "traditional". They have received higher education, by which most often is

6. Tim Carmichael, "British 'Practice' Towards Islam in the East Africa Protectorate: Muslim Officials, Waqf Administration, and Secular Education in Mombasa and Environs, I 895-1920", Journal of Muslim Minority Affairs, I7 (1997), pp. 293-309, 294. 
meant "Western" university education, and they see themselves as independent from the ruling elite or from institutionalized traditional politics. They are, however, at least partly enmeshed in existing power structures. The évolué group only came into existence from the late i950s onwards. After Malian and Nigerien independence in I960 the new regimes saw educating the Tuareg as a necessity to the modern development of the nation.7 Therefore, in the r 970 s their number increased significantly as the young children sent to school in the I960s came of age. I will here present this particular group as a "modern elite" which takes an intermediate position between the conservative tribal leaders and another group of intellectuals (and new leaders), which is the most important to this article.

This last group, generally called ishumar, are truly "popular intellectuals", fitting the description given in this collection. The ishumar are mostly autodidactic intellectuals whose reflections developed through the experiences of international travel, smuggling, and (un)employment in various industrial sectors previously unknown in Tuareg society. Their reflections turned largely around the modernization of Tuareg society and the need for political independence through revolutionary action. The latter discourse, typical for this group in Tuareg society, developed largely through exposure to mediatized revolutionary discourse in Algeria and Libya, which they compared to and measured against their personal experiences. This political reflection would ultimately lead to the Tuareg rebellions in Mali and Niger.

The ishumar can be perceived as an elite, first of all because they saw themselves as such. From the I980s onwards, those ishumar involved in the preparation for armed rebellion perceived themselves as a revolutionary military vanguard which would lead their people to independence. Second, they can be seen as an intellectual elite among their fellow immigrant workers, as they put their thoughts on migration, modernity, and politics into words: the poems and songs of the teshumara movement. They were the ones who produced knowledge, even if part of this knowledge concerned experiences they had in common with their less articulate audience.

The categorization of these groups is, of course, more academic than real. These groups partly overlap. Part of the évolués shared in the teshumara experience, joined the rebel movements, and came originally from an organic intellectual milieu. One example is the famous Tuareg poet, Mahmoudan Hawad, a member of the Ikazkazen clan, which is part of the ruling elite in Niger. Living in chosen exile in France, Hawad started

7. Unfortunately, the English language has no standardized name for the inhabitants of the Republic of Niger. Many erroneously refer to them as Nigerians, which would make them inhabitants of Nigeria, which is another country. I will here use the term Nigerien. 
his intellectual career as an ashamor, but during the rebellion he published many a polemic in Nigerien (and French) newspapers in the finest évolué tradition.

\section{TESHUMARA: THE ORIGINS OF A NEW INTELLECTUAL REVOLUTIONARY ELITE}

Participants in the Tuareg uprising against the Nigerien and Malian governments in the I990s often refer to it as ath-thawra, which in Arabic means "revolution". However, it can be argued that the "revolution" took place before the rebellion, and consisted of the changes society underwent prior to the uprising. The major changes were a partial shift from a pastoral nomad society and self-sufficient economy, to an urban existence of wage labour and the introduction of new consumer items. These major changes brought along shifts in gender relations, cultural forms of expression, education, and politics. It was also the change from a society living in a geographically limited (if large) and coherent region, to a diaspora around West Africa, the Maghreb, and, to some extent, Europe.

The Tuareg name for the movement that actively promoted this revolution is teshumara, a derivative of the French chomage: unemployment. Those who followed this new way of life were called ishumar: unemployed. ${ }^{8}$ An ashamor was first of all someone who had (partly) abandoned pastoral life in favour of employment in other economic sectors. In large parts of the Tuareg world, this meant migration, since economic alternatives hardly existed within society. An ashamor would travel in between jobs, during which period he was unemployed.

The teshumara was a direct consequence of the droughts that hit the Sahara and Sahel in the I970s and I980s. For centuries, the Tuareg had carved their existence out of the desert as pastoral nomads and caravan traders, fully dependent on their livestock for their livelihood. The droughts left them with less than 20 per cent of their former herds in cattle, small ruminants, and, especially camels, still alive, and thus with a strong need to look for other means of existence. Especially among the small group of contemporaneous Western-educated Tuareg intellectuals, the drought led to rethinking pastoral life. Many reached the conclusion that pastoral existence had no future.

Pastoralism as we have always practised it is no longer an honourable option in our days. For different reasons it is condemned to be abandoned or at least to be

8. The masculine plural is ishumar; masculine singular: ashamor; feminine singular: tashamort; feminine plural: tishumarin. Teshumara is the indicative noun: "unemployment", or "the way of unemployment", meaning both the movement and the culture it produced. 
restructured. It is not a goal in itself, and a Tuareg is not in the least predestined to be born and die as a pastoralist. ${ }^{9}$

At present, the Sahara on the whole rises from a kind of medieval lethargy to wake up and to open up to a modern world. [...] And the nomads? They too are condemned, not to disappear, but to become something different. They are condemned to disappear as nomads, but not as human beings. The question inevitably asked, is to know what the nomads are and what they will do, now that they have lost the major part of their herds. ${ }^{10}$

As few new means of existence could be found in Mali or Niger, many former herdsmen moved to the Maghreb and elsewhere in West Africa. Employment was found in various occupations, such as salaried herding, agriculture in the oasis towns of the Sahara, construction work and masonry, car mechanics and even fishery. Most jobs were temporary, and many moved from town to town, from job to job. As most jobs were to be found in the cities, the teshumara was an urban culture, taking shape in the booming Saharan cities of Algeria and Libya, such as Tamanrasset, Ghat, Ghadames and Sebha.

A profitable but dangerous activity was smuggling. ${ }^{\text {II }}$ During the I970s and I980s, most smuggled goods consisted of basic foodstuffs, bought in southern Algeria where prices were subsidized and sold in Mali and Niger to the refugees and victims of the droughts. With the advent of the rebellions, the smuggling in arms, petrol, and cars took off to sustain the rebellion. After the rebellions, this transnational traffic network would become integrated in a larger trans-Saharan trafficking network generally known as the "Marlboro Road" after its main merchandise.

As a last, but certainly not least, professional occupation soldiery should be mentioned. This profession was, however, not taken up by many; one should think in terms of hundreds, and it was not taken out of economic interest, but out of political motives. The teshumara was more than a social economic culture. It ultimately evolved as a nationalist political movement seeking Tuareg independence. This movement is generally known as tanekra, Tamasheq for uprising, which will be treated more fully below.

It should be emphasized that not only young men migrated. Young women also travelled to the cities of Southern Algeria looking for a better life. They often traveled alone. The mobility and independence of Tuareg women made many Algerians look upon these female immigrants in disapproval. ${ }^{12}$

9. Anonymous I, Quand le chef travaille, le peuple le suit (unedited ms., personal archives, n.p., n.d. (1990)). Document circulating in Niamey in 1990 among Tuareg évolués [hereafter, Quand le chef travaille).

ı०. Acherif ag Mohamed, "Les possibilités agricoles dans le Cercle de Kidal”, (Mémoire de fin d'Études, ENSUP Bamako, I977), p. 37.

I . See Georg Klute, "Die Rebellionen der Tuareg in Mali und Niger" (Habilitationschrift, Universität Siegen, 200I). 
City life also changed the simple everyday habits of society. To a Tuareg, the ideal repast consists of fresh milk and fat meat, with three glasses of sweet tea for dessert, but the diet changed. Cereal products and vegetables were added, fresh milk was substituted with milk powder, and butter with olive or peanut oil. While most women in the Maghreb kept their customary dresses, the male ishumar dress code changed sharply from customary dress. Especially telling were the changes in wearing the male turban and veil, through which individual male honour is expressed. The customary veil and turban are a complex, multi-layered wrapping of various cloths, sometimes as long as 20 metres. In general, the less of the face is visible, the more a man is guarding his honour. The ishumar deliberately expressed the turmoil they found their society to be in, and their desire for radical changes in the way they wore their turban. The multiple layers were abandoned for a single cloth, the length of which was reduced considerably to about 4 metres. This shortened turban was wrapped around the head in an uncaring fashion, yet carefully leaving the face exposed, expressing their chosen status as young and irresponsible men and their rebellious state of mind. But it also explicitly expressed the notion that society had lost its honour and found itself in turmoil. ${ }^{13}$

When the ishumar gained enough money, new consumer items became available to them, such as watches, sunglasses, cassettes, cassette players and guitars. The last three items were especially helpful in forming ishumar cultural expression. The ishumar developed their own musical genre: alguitara, a particular style of guitar rock. ${ }^{\mathrm{I}}$ Musical inspiration was found in the repertoire of Jimmy Hendrix, for his virtuoso solos, and Dire Straits for the simplicity and clarity of their chord schemes. Despite these influences, al-guitara developed into an original sound with strong influences of local musical genres.

The first to make al-guitara music was a group of men from the Malian Adagh mountains who called their band, Taghreft Tinariwen, "Let's Build up the Countries", better known as Tinariwen, or "The Deserts". In the coming decades, the songs by Tinariwen or its individual members would accompany the teshumara and tanekra resistance movement, as well as the rebellion at its various stages. Tinariwen's musical sound remained long subordinate to its message, which was one of reflection on Tuareg existence.

I2. Rachid Bellil and Badi Dida, "Evolution de la relation entre Kel Ahaggar et Kel Adagh", Les cabiers de l'IREMAM, 4 (1993), pp. 95-I IO.

I3. Hélène Claudot-Hawad, "Visage voilé et expressivité", in idem, Les Tonaregs. Portrait en fragments (Aix-en-Provence, I993), pp. 29-43; and Susan Rasmussen, "Veiled Self, Transparent Meanings", Ethnology, 32 (I99I), pp. Ior-II 7.

I4. Nadia Belalimat, “Le Chant des fauves': Poésies chantées de la résistance touarègue contemporaine” (Mémoire de Maîtrise, Université Paris X, Nanterre, 1996). 
We are mangled between the Arabs and the West, But even more so by Mali against whom we fight. $I$ have a question for my brothers in my nation,

Consider the situation you are in. ${ }^{\text {Is }}$

But slowly the message changed from one of despair to one of hope for a better future through common action:

We pull up our trousers and fasten our belts,

We no longer accept this maltreatment we endure. ${ }^{16}$

Through their songs, but also through the individual poems of other ishumar, the social and political messages of the teshumara were transfused in Tuareg society. Put simply, the message was: "We, the Tuareg people have suffered under oppression and droughts since African independence in the I96os. Independence left our country divided between various nationstates. Since then, we have moved away from kin and country to the Maghreb. We need to reunite and liberate our country, so that we can become prosperous again." This idea was already expressed in one of the oldest al-guitara songs:

Friends, hear and understand me.

You know, there is one country,

One goal, one religion.

And unity, hand in hand.

Friends, you know

There is only one stake to which you are fettered

And only unity can break it. ${ }^{17}$

Musicians would perform at ishumar parties, where those who had cassette recorders recorded the sessions, which were then copied by new listeners. Possession of cassettes was dangerous and could lead to imprisonment. During the rebellions, cassettes were spread more easily, but as both rebellions, especially in Mali, evolved in an internal struggle between clan or status-group based movements, the music changed as well. Some musicians would put their poetic talent to the service of one particular status-group or clan, while others wrote songs calling for reconciliation and

I 5. From "We Are Mangled by the Arabs", by Keddu ag Ossad (Irreguenaten), n.d., in Belalimat, "Chants des fauves", song I I. All poems cited in this article are part my own corpus, or that of two other unpublished works: Klute, "Rebellionen", and Belalimat "Chants des fauves", or published works. Translations into English are mine, based on my own versions in Tamasheq as well as transcriptions and translations in French and German by others. Poems cited will be referred to by title (often the same as the first lines of the song) poet, tribal origins, date/year of composition, corpus, or previous publication.

16. From "We Pull Up Our Trousers and Fasten Our Belts", by Cheick ag Aoussa (Irayaken), 1983, in Klute, "Rebellionen", annexe rebel songs, song 7.

17. From "Friends, Hear and Understand", by Intakhmuda ag Sidi Mohamed (Kel Essouk), i978, Klute, "Rebellionen”, poem I, Belalimat, "Chants des fauves”, poem I. 
reunification. Possession of cassettes containing one particular message or the other could then also lead to repercussions. In turn, these repercussions could lead to new poetry, spread on new cassettes.

A famous example is a long poem by Ambeyri ag Rhissa, a well known and highly respected Western-educated intellectual from Kidal, who condemned the rebellion and who was therefore taken hostage by the rebels for a considerable period. He then put his experiences into a poem, which was thereafter distributed on cassette. After the rebellion, the poem was sometimes broadcast on local radio, to remind the inhabitants of Kidal of the disruptive effects of the internal conflicts. After the rebellion, alguitara became "mainstream" in both Mali and Niger, and even abroad. Tinariwen has put out two CDs, The Tisdas Sessions (the title is in English and Tamasheq) in 2000 and Amassakoul in 2003, available at your CD store, while they tour the European "world music" festivals. Some other former ishumar groups, notably Tartit (in Belgium), are even permanently based in Europe.

\section{ISHUMAR AND ÉVOLUÉS: EDUCATIONAL DIFFERENCES}

The teshumara was not the only path to change open to the Tuareg. It was particular to those who migrated to the Maghreb. Tuareg who moved to coastal West Africa had different influences transforming their way of life. Already, in colonial times, a number of ineslemen had migrated to the Hedjaz, where they took up religious professions. This migration continued after independence. From the I980s onwards, a major access to a then already globalizing world, especially in Agadez, Tamanrasset and the Tassili mountains, was the arrival of tourists, which opened new vistas to those who spoke French as guides, drivers, and tour operators.

A more important alternative to the teshumara was formed by the path of formal education. In colonial times, both the Tuareg elites and the administration were hesitant towards Western education. The first primary schools in the Sahara open to Tuareg children were only created in 1947, and as late as 1955, Claude Blanguernon, head of education in Algerian Tamanrasset, still did not believe in the need to bring the Tuareg to a high level of education. He argued that, "It won't be good since the instructed nomad will find himself cut off from his tribe, his customs and, fatally, he will not be able to remain a nomad." 18

Most Tuareg believed that French education would turn their children away from Islam, and therefore were reluctant to send them to school. Therefore, fixed quotas of children to be educated per tribe were set by the French colonial governments. Most noble families reacted to this measure

I8. Claude Blanguernon, "Le Hoggar et ses écoles nomades", Documents Algériens, is (Algiers, I955), p. 6. 
by sending the children of their servants to school instead of their own. As in most other West African societies, Tuareg society had forms of servitude and dependency, persisting throughout the colonial period, despite the official abolition of slavery by the authorities. These servants remained with their (former) masters, obeying their wishes, in this case to be educated. This educational lack of effort from both sides changed in independent Mali. In the administrative cercle, Kidal for example, only one school had existed since 1947. Under the Keita regime between I 960 and I 968 an additional five schools were built. ${ }^{19}$ The number of Tuareg lycéens too rose over the years, with equally growing numbers entering higher education at Bamako's Ecole Nationale Supérieure or Ecole Nationale de l'Administration. A number of Tuareg followed higher education outside Mali, mostly in Algeria but sometimes as far away as Riyaadh, Rabat, Khartoum, Nouakchott, Kiev, Moscow, or France.

This newly created intellectual elite with Western standards could enter the state administration, or they could offer their services to Western NGOs, which abounded in Northern Mali and Niger, especially after the droughts. Like their ishumar kindred, these évolués, as they are generally called (a highly pejorative term, nevertheless locally employed) lived in cities, where they were exposed to new cultures and ways of thinking, new consumer goods, new cultural expressions, and forms of organization.

To the ishumar, education meant something different than reading, writing, and calculus. Teshumara and formal education were not mutually exclusive, although their efforts in these matters were hardly sustained, and most of their interests were in practical skills such as mechanics, masonry, or electronics, which they acquired on the job. But to them, education meant political education and awareness about the situation Tuareg society found itself in. The nicknames the évolués received from their ishumar counterparts are revealing. They were called the ondit or entoucas, after the French expressions on dit que and en tout cas, which they often employed even when speaking Tamasheq. ${ }^{20}$ They were accused of having knowledge but not using it for the benefit of their people, or even of outright betrayal of the Tuareg cause. Finally, they were accused of being acculturated.

\footnotetext{
I heard you are educated,

We have not seen your benefits,

Our bistory is known to all

[...]

And you tell me you live normally,

An organized, quiet life.
}

19. Ibrahim Litny, "Systèmes éducatifs et société touarègue: les Kel Adagh du nord du Mali" (Mémoire de diplôme, EHESS, I992), pp. I57-158.

20. Nadia Belalimat, "Qui sait danser sur cette chanson, nous lui donnerons de la cadence: Musique, poésie et politique chez les Touaregs”, Terrain, 4I (2003), pp. I03-I20, I I 2. 
Since your birth you run in vain,

Surrounded by enemies.

The easy life always escapes you,

Unless you make some effort to engage yourself,

To reach that truth that belongs to you. ${ }^{2 \mathrm{I}}$

While the ishumar developed a more and more radical political outlook, calling for armed revolution and independence, the Western-educated Tuareg had a far more moderate standpoint with regards to the state and the necessity of violence. The évolués reproached the ishumar with being ignorant of the realities of this world, uncivilized, and engaged on an irrelevant cause. Changing society was necessary, but not along the vague and half-conceived ideas of the ishumar. The educated, in their turn called the ishumar, mazbuten, from their favourite colloquial Arabic expression mazbut: "right", "OK".22

Whereas the ishumar spoke out against the évolués in their poetry, their "victims" remained rather silent. Most documents by évolués, written prior to the rebellion, do not refer to rebellion because of either contempt for the subject, or ignorance of the intentions of the ishumar, or knowing of their intentions and not wanting to jeopardize the cause. After all, the évolués wrote in French, a language understood by their future adversaries. It was only during the later years of the armed conflicts, when the national idea had already been mitigated or totally abandoned, that some openly spoke out against the initial cause in a post-fact "told-you-so" fashion.

In his book, A Peace of Timbuktu, on the rebellion in Mali and its ending, United Nations Development Programme (UNDP) coordinator, and former employee of the NGO Norwegian Church Aid (AEN), Ibrahim ag Youssouf, gives ample space to describe the whereabouts of his former AEN colleague and fellow évolué, Zeidane ag Sidi Alamine. From late 1994 onwards, Zeidane directed the rebel movement, Front Populaire de Libération de l'Azawad (FPLA), previously headed by ashamor and Chad veteran, Ghissa ag Sidi Mohamed. Zeidane played a significant role as peace-broker between the, by then, highly embroiled movements and the Malian government in the final peace of March i996. Fellow évolué, Ibrahim ag Youssouf, describes Zeidane as, essentially, "a man of peace" who had always been against the rebellion and who had integrated the movement to stop the conflict. ${ }^{23}$

On the other hand, a number of educated Tuareg lived an ashamor existence for a part of their lives, especially those who pursued an

2r. From "I Heard You Are Educated and Understand”, by Tinariwen, (Kel Adagh), Libya, 1986, Belalimat, "Chants des fauves", no. ro, Klute, Annex, no. I I.

22. Interview with Moussa ag Keyna. Leiden, 4 October $200 \mathrm{I}$.

23. Richard Poulton and Ibrahim ag Youssouf, A Peace of Timbuktu: Democratic Governance, Development and African Peacemaking (Geneva [etc.], I998), pp. 70-80. 
educational career abroad as migrants in Algeria or Libya. They too were confronted with semi-legality, discrimination, expulsions, and the other ishumar experiences. The differences between évolués and ishumar were therefore not always so large, especially during the r970s and I980s. A number of these educated ishumar would become influential members of the tanekra movement during one period or another. Especially the Europeanbased students would come to hold a special position during the rebellion, as they dispersed information on the rebellion in Europe and provided contact between the rebels and various organizations. Good examples of these are the newsletter, Lettre Touarègue, written and diffused as photocopies by Ibrahim ag Litny, then a student at the Ecole des Hautes Etudes en Sciences Sociales in Paris, between February 1993 and January 1994, and the newsletter, Temoust Survie Touareg, written by Bilatan Attayoub, a Lyon-based computer engineer, which was also published on the Web.

The best example of Tuareg Western education and cosmopolitanism intertwined with political activism is probably the best-known Tuareg ever: Mano Dayak. Born in the Nigerien Aïr mountains in I950, Dayak was forcibly integrated in a French school when he was eight years old. He continued his scholarly career, studying anthropology in Paris and Indianapolis, and upon return to Niger, began a tourist agency through which he met his future French wife. He was one of the key organizers of the Paris-Dakar car rally, and collaborated with Bertolucci in the making of the blockbuster movie, The Sheltering Sky. Although Dayak had never been a true ashamor, many of his employees had, such as later rebel leader and minister in many a Nigerien government, Ghissa Boula. After the rebellion broke out in Niger, Dayak started his own rebel movement, the Front de Libération Temust, with the help of his employees and, most likely, his connections in France. Like no other, Dayak knew the importance and possibilities of favourable media exposure to indigenous peoples' insurgency movements. It was partly through his media contacts and his cooperation in mediatizing the Tuareg rebellions in Mali and Niger, that the conflict became seen in a light favourable to the Tuareg cause. $^{24}$

Despite these examples, however, animosity between these educated Tuareg and the "true" ishumar could run high. It would come especially to the fore during the rebellions, when the rebels had no choice other than to let the educated negotiate with the Malian and Nigerien governments in their place, as the rebels saw themselves unfit to do so, or had been deliberately sidetracked by the authorities. With these disputes between ishumar and évolués, I have come to the political debates on the structure of Tuareg society.

24. Michel Vallet, "In Memoriam: Mano Dayak”, Le Saharien, I 36 (1996), pp. 50-53. Dayak’s autobiography, ghost-written by a German and a French journalist, served especially well in mediatizing the conflict: Mano Dayak, Touareg, la tragédie (Paris, I992). 


\section{POPULAR VERSUS TRADITIONAL INTELLECTUALS}

Ishumar and évolués might have had their internal differences, but on one thing they could generally agree: the need to change society and social structure. In spreading this ideal, they found the traditional intellectuals, the tribal leaders, and ineslemen religious specialists in their way. The latter two groups did not share the vision that society needed to change.

Debates in the I970s and I980s between both groups of intellectuals focused on two key issues. The first was the relation between Tuareg society and the postcolonial states they lived in, within which the traditional elite functioned, and from which they acquired part of their legitimacy, and which the new elite perceived as detrimental to Tuareg social and cultural survival. The second key issue was the nature of Tuareg society itself, with its tribal structures and social inequalities expressed in status groups and tribal hierarchies. Again, where the traditional elite of tribal leaders and ineslemen found themselves at the apex of this system, a position they did not deem necessary to relinquish, the new elites objected to this system both on ideological and practical grounds.

\section{Nation and state}

As has been noted above, the teshumara social cultural movement brought forth a political nationalist movement generally called tanekra, which means "insurgency". In September 1979, about seventy ishumar gathered in the Libyan city of El Homs under the aegis of the Libyan government, to discuss their revolutionary ambitions. The congress of El Homs led to the creation of al-Jabha ash-Sha'biyya li Taghrir Sahara' al-Kubra al'arabiyya al-Wasta: the Popular Front for the Liberation of the Greater Arab Central Sahara (FPLSAC). The FPLSAC was endowed with a political bureau, and a military training camp at Ben Walid in early I980. Both the camp and the office were closed in late $\mathrm{I} 98 \mathrm{I}$, following a shift in Colonel Khaddafi's political strategies. It should be stressed that the Libyan government outlawed the FPLSAC after the closing of the Ben Walid camp in $198 \mathrm{I}$. Upon closing the camp, the recruits were offered the opportunity to enrol for the Palestinian cause in Lebanon. About 200 recruits volunteered and served with the Popular Front for the Liberation of Palestine in the Bekaa valley and Beirut until Israel ousted the Palestinian forces from Lebanon in $1982 .{ }^{25}$ In 1983 , the Libyan government again recruited Tuareg fighters, this time to fight for Libyan interests in Chad.

These two groups of men would form the tanekra movement, the inner

25. Based on various interviews with former rebels. Written evidence of their time in Lebanon is left in correspondence of this group with the PLO, documented in Raphael Israeli (ed.), PLO in Lebanon: Selected Documents (London, I983), pp. 192-201. 
core of officers and organizers of the rebellions of the I990s. It was this movement which formulated the nationalist outlook on the world that found its expression in the Tuareg rebellions of the I990s. The tanekra vision of colonial conquest, rule, decolonization, and their effects on society, are nicely summed up in the following text written by a member évolué:

The colonizers and their successors have all stressed the stratification of Tuareg society, opposing Imajighan [nobles], Imrad [free], and Ineslemen [religious]. They have put one against the other, and one group against the other. For a moment all fell into these sordid traps, forgetting their Tuaregness [targuité], their identity and the hatred their enemies festered for them. It is this hatred and the exclusion, of which we all are victims, which in the end binds us and makes us conscious of our destiny as a community. ${ }^{26}$

The calamities striking the Tuareg in the postcolonial period - an abortive rebellion in Mali in I963, two droughts, and general (perceived) discrimination by the state - made it all the more clear to the ishumar that Tuareg independence was necessary. Some of these calamities would not have struck if independence had been given to the Tuareg straight away in I960, or so they thought. The tanekra movement was all about regaining independence, expressed in ideas on territory and the Tuareg nation. As in almost all nationalist discourses, Tuareg ideas on nation and country focused on concepts of land and nation, in Tamasheq, akal and temust. Within the tanekra movement the term akal, ground or territory, came to embody the territory of all Tuareg on which an independent state was to be formed. Temust, from imas "being", originally meant "identity" or "self". It acquired political meanings in the teshumara. Cultural unity was stressed through elements that had always been criteria of unity within the Tuareg world, notably the Tuareg language. "The foundation of our identity is TAMAJAQ. Our language, the central axis of our society, is the most precious we have to preserve. We can lose everything, if we can save the Tamajaq [sic], we save our specificity. Nothing distinguishes a people more from another people than language!" ${ }^{27}$

Disregarding the obvious paradox in defending one's identity and language in French (more or less proving the point of the ishumar, who composed their lyrics in Tamasheq, against the évolués), a few things are striking when looking at the Tuareg national idea as it was imagined in the I970s and I980s by the new intellectual elite. The first is that a people which organized society and politics on the basis of fictive kinship ties, expressed in clans, based its nationalist ideal first and foremost on

26. Anonymous II, "De la marginalisation des Touaregs au Niger", (unedited ms., Paris, I994), p. I4.

27. Anonymous I, Quand le chef travaille. 
territorial notions (akal). There were very specific reasons that "soil" was taken as the binding national factor, instead of "blood". The nationalists of the tanekra perceived kinship relations in politics as a major obstacle to successful political unification of the nation.

Indeed, the clan structure, as well as the existing divides between independent states, kept hindering the nationalist movement throughout its existence. The Tuareg from Algeria and Libya, the Kel Hoggar and Kel Ajjer, never joined the liberation movement. Already, during the I980s, Tuareg from Mali and Niger, once united in the FPLSAC, broke up along the lines of the nation-states they sought to overthrow, Mali and Niger, to continue in two "national" movements that started revolts independent of each other (in Mali in 1990 and in Niger in 1992) with hardly any communication between the two. In both cases, the movement would split along lines of clan affiliation soon after the outbreak of revolt, proving the failure of the nationalist ideology.

\section{Society, caste, tribes, and chiefs}

The second key issue between old and new elites, as described above, was the hierarchical organization of Tuareg in caste and clans, at the apex of which stood the tribal chiefs. The clan and caste system was an abhorrence to the ishumar. They derived their identity from a common experience of marginalization within their host societies and within Mali and Niger, in which tribal or clan affiliation had no meaning. At the margins of Algerian and Libyan society, the teshumara formed a network of men and women who largely depended on trust in each other for economic and social survival. Coming as they did from all parts of Mali and Niger, and from all the various tribes, tribal affiliation could not serve as a common factor establishing social coherence and group loyalty among ishumar. On the contrary, the constant competition over hierarchy between clans could only sow discord among their ranks. It should therefore be abolished. One of the main rules of the ishumar was that one should never mention someone's clan affiliation. Only using someone's name or nickname was allowed.

The idea that feelings of clan affiliation should be suppressed had been enhanced by the nationalist and socialist political discourses the ishumar had been exposed to in Mali, Algeria, and Libya. In Algeria, national unity and an Algerian identity were created during and after the war of independence at the expense of other solidarities. That this identity was contested by both advocates of Islam and Berber culture made the FLN's nationalist discourse all the more insistent on the unity of the Arab working masses of Algeria. At the primary schools founded by the socialist Keita regime in Mali, the idea of equality had been vehemently propagated. The Keita regime had depicted the chiefs as colonial feudal lords working 
against the interests of the laborious Malian masses. Indeed, to many Tuareg, those tribal chiefs who owed their legitimacy to state appointment had grown synonymous with the collection of taxes, the forced education of children and other forms of coercion.

Ironically, although tribal societies are often portrayed as premodern, they are in fact essentially modern. They were created during the first few decades after colonial conquest. The tribe and the fraction were based on the French comprehension of the Tuareg social political system. The term tribus was believed to be the proper translation of the term ettebel, or clan federation, the highest level of Tuareg political organization. Fraction was seen as the proper translation of the term tewsit, or clan. After independence, the new Malian administration set out on an active policy to modernize society on a basis of "tradition", and to undo parts of the administrative colonial heritage. Paradoxically, to do so part of the colonial structure was now formalized by law. The new regime believed that in "traditional" African society the village had been the pivot of society, and therefore proclaimed the village to be the basic unit of Malian political, economic, and administrative organization. Parallel to the village, the fraction, an essentially colonial structure, became the basic "traditional" unity of administrative, political, and economic organization in nomad societies, which did not have villages.

Despite the inherent modernity and constant modernization of the tribal system, to many Tuareg intellectuals, tribalism is seen as a premodern obstacle to modern life. Ironically, to transform the structure the new elites feel compelled to use it. By installing the fraction and its institutions de jure, the procedures and conditions of creation and dissolution became standardized. The main condition to form a new fraction is that one needs roo potential members, who agree upon a designated chief and elect among themselves a fraction council (often consisting of the initial organizers of the new fraction). The potential chief and his council can then demand the necessary administrative forms, fill them in, and submit their demand.

The formalization made it possible for others than the chiefs or the administration, such as former rebel leaders, to create fractions to the detriment of traditional leadership. The procedure became very popular shortly after the second rebellion and still is today. In 1974 there were 65 fractions in the cercle Kidal, a number that had been more or less stable since the I940s. In 1996 their number had almost doubled to I I $4 .{ }^{28}$ "It won't be long before everybody is his own fraction" as one of my interlocutors cynically observed. The new fractions are often based on the social and political dynamics within a terosit as clan, and between various internal tendencies.

As for the position of the tribal chiefs, their vision on the rebellions 
became clear soon after the rebellions broke out. In September I990, two months after the outbreak of the rebellion in Mali, the tribal chiefs made a declaration, broadcast on radio and television, in which they qualified the rebels as "bandits and traitors, committing unimaginable follies disturbing the tranquillity and stability regained after years of merciless drought", and "denounced and condemned with their last energy the hideous acts the bandits perpetrated". ${ }^{29}$ That these chiefs had indeed something to fear from the rebels, was most clearly demonstrated by the abduction of Intalla ag Attaher, the paramount chief of the Kel Adagh of northern Mali, by the rebel movement ARLA in March 1994. In response, Intalla created a heavily armed bodyguard, which functioned as a vigilante movement of its own.

As elsewhere in postcolonial Africa, "traditional" tribal leaders had remained intermediaries between population and government in both Mali and Niger. Yet, the fate of tribal leaders in Mali and Niger differed sharply after independence. In Niger, independence brought to power the Nigerien Progressive Party, which was dominated by the traditional chiefs. A coup d'état in 1974 by Colonel Seyni Kountché did not alter their position. In Mali, independence was brought by the staunchly Marxist US-RDA, whose policy to the Tuareg chiefs remained ambiguous throughout its reign. Its desire to do away with these "feudal remnants of colonialism" entirely were abrogated by the need to have them collaborate in the implementation of policies. Thus, although the chieftaincies were formally abolished in 1961, the chiefs retained informal power in collaboration with the government. After the I 968 coup d'état and the creation of the single party UDPM in 1979, which was less hostile to traditional leaders, a number of Tuareg tribal chiefs or their sons managed to have themselves "elected" as representatives of their constituencies. Thus, the traditional elite regained power in national politics and managed to fortify their position in Mali, whereas they had never really lost it in Niger. It can therefore easily be concluded that the old elite had nothing against a system it owed its existence to.

Still seen by the respective governments as both the legal (as members of parliament) and legitimate representatives of the Tuareg population, some chiefs managed to play an important role in brokering peace in Northern Mali. After the conflict in Northern Mali degenerated in 1994, tribal chiefs in the Niger Bend area played a crucial role in establishing a final peace. Through their efforts, these chiefs regained their status as the true protectors in and of Tuareg society. They shared this position with those évolués who had taken over leadership within the rebel movements and 
who had negotiated earlier peace deals. Gradually, the true ishumar military commanders of the rebellion lost their influence.

\section{THE OUTCOME}

So what came of all the proposed changes to society and the nationalist zeal of the new intellectual elites? As most nationalist insurgency movements in Africa, the Tuareg separatist movements failed to reach their goals. When the rebellion broke out in Mali in 1990 and in Niger in I992, it was received with some enthusiasm by the Tuareg population, who saw the military violence in a "traditional" way as a restoration of lost collective honour endured during the colonial and postcolonial periods. This was perhaps especially true in Niger, where rebellion broke out in 1992, only after initially peaceful attempts to settle Tuareg grievances. Even when army retaliations on the civil population intensified, support did not wither away, and was even strengthened. But with the continuation of the conflict after initial peace agreements were signed, popular support for the rebellion died down in both Mali and Niger. The Tuareg population (not unjustifiably so) accused the rebel elite of being out for personal gain to the detriment of the common people. Another group strongly denouncing the rebellion were the traditional intellectuals, the tribal chiefs, and the ineslemen or religious specialists. It is, of course, not surprising that the chiefs were against the rebellion as they were perfectly aware that one of its aims was to undermine their position.

However, partly as a result of the rebellions, both Niger and Mali, which were military dictatorships at the outbreak of the rebellions, underwent a process of democratization and administrative decentralization. The communal elections of June 1999 in Mali were the first ever in which Tuareg could vote other Tuareg into power at local level. The rather bitter and intense struggle for votes between some of the candidates was an indication of the enthusiasm for this relative form of political independence.

The idea that society needed to change was not shared by society and probably not even by all ishumar in their hearts. Many rebels fought more out of loyalty to fellow tribesmen who had initiated the rebellion, than out of full understanding. As one informant put it:

You know, of all the fighters who had been trained in Libya, perhaps only twenty percent understood the goal. The others had understood nothing, they just went along. With the Tuareg, there is this thing we call teylelil. If there is one who has a goal, the rest follows automatically. Without knowing what the goal is, without thinking. That is teylelil. But we are also jâbil [unknowing, uneducated]. Give a jâbil a gun and the gun controls the man, not the man the gun. $3^{30}$

30. Interview with Lamine ag Bilal, Gao, 20 June 1999. 
The internal hierarchy between clans and tribes was especially hard to root out. Both rebel movements in Mali and Niger underwent a process of fragmentation in a mixture of clan affiliation and political differences between various ishumar and évolué intellectuals.

With this fragmentation, the unending internal fights, the continuing army retaliations, the creation of vigilante movements by neighbouring ethnic groups, and the general insecurity in the Tuareg regions, support by the population declined to zero, while more and more attention was again paid to the traditional intellectuals, the tribal chiefs. Thus, the balance of power between traditional and new elites was reset. After the decentralization of Mali in the late I99os and the introduction of local democracy, the struggle over political power between both elites continued through more peaceful means.

\section{CONCLUSION}

In the past half-century, dramatic socio-economic and political transformations in Tuareg society (brought about by ecological and political changes in the region) have led to the emergence of new intellectual and political elites. These new intellectuals have sought to understand and influence these changes with the aim of ensuring the continuing existence of the Tuareg as a people. Those most consciously thinking about and modelling these changes, were the ishumar or "unemployed". From their concrete experiences and way of life as migrant labourers (who were unemployed part of the time) in Libya and Algeria, these "unemployed" developed a political outlook that may be described as nationalist and, in a way, socialist. Members and adherents of this informal network or movement of popular intellectuals organized a more formal movement, the tanekra or uprising, which sought to materialize these nationalist and social aspirations through armed resistance against the state.

The initial political aims of the rebellions were twofold. The first was to win independence for a nation-state to be created. This goal was quickly abandoned in favour of demands for more autonomy, which was eventually granted in both Mali and Niger through the decentralization of the national political structure. The second was to enforce social political changes in Tuareg society itself, by abolishing the clans and tribes and by breaking the power of the traditional tribal chiefs and Muslim specialists (ineslemen). This second goal was never reached. Soon after the outbreak of the conflicts, the united rebel movements in both Mali and Niger broke up along the lines of clan affiliation. Specific tribes or status groups (castes) were represented by their own movement. When these movements started to fight among themselves, leading to the degeneration of the conflict and to general insecurity in northern Mali and Niger, the traditional elites were instrumental in brokering a final peace. 
Nevertheless, the rebellions that broke out in 1990 in Mali and in 1992 in Niger, formed the culmination of years of conscious and active revolutionary nationalist struggle. They also formed the culmination of decades of profound changes in Tuareg society. The initial ecological and economic causes of these changes were perhaps unintended, but the changes they provoked were actively and consciously shaped by an intellectual and cultural elite in search of modernity. Thus, one could argue, the "revolution" in Tuareg society had taken place before "the revolution" broke out. 